\title{
Microbial activities, carbon, and nitrogen in an irrigated Quartzarenic Neosol cultivated with cowpea in southwest Piauí
}

\section{Atividade microbiana, carbono e nitrogênio de Neossolo Flúvico cultivado com feijão-caupi irrigado no sudoeste piauiense}

\author{
Larissa Castro Diógenes ${ }^{1}$; José Ferreira Lustosa Filho ${ }^{2 *}$; Alessandro Franco Torres \\ da Silva ${ }^{3}$; Júlio César Azevedo Nóbrega ${ }^{4}$; Rafaela Simão Abrahão Nóbrega ${ }^{4}$; \\ João Irene Filho ${ }^{3}$; Aderson Soares de Andrade Júnior ${ }^{5}$
}

\begin{abstract}
The aim of this study was to evaluate microbial biomass and total organic carbon and nitrogen of an irrigated Quartzarenic Neosol cultivated with two cowpea cultivars in Bom Jesus, Piauí, Brazil. The experiment was conducted in a randomized experimental block design in split plots. The plots consist of two cowpea cultivars (Aracê and Tumucumaque) and the subplots were composed of five different irrigation regimes $(\mathrm{L} 1=108.2 ; \mathrm{L} 2=214.7 ; \mathrm{L} 3=287.9 ; \mathrm{L} 4=426.1$, and $\mathrm{L} 5=527.7 \mathrm{~mm})$. Soil samples were collected at a depth of $0-0.20 \mathrm{~m}$ in order to evaluate basal soil respiration, microbial biomass carbon, metabolic quotient, microbial quotient, content, and storage of soil carbon and nitrogen. Basal soil respiration, microbial biomass carbon, microbial metabolic quotient, and microbial quotient are influenced by the interaction between cowpea cultivars and irrigation. The cultivar Aracê showed greater stimulus to the microbial community, while the irrigation regimes with 214.7 and $287.9 \mathrm{~mm}$ (60 and $90 \%$ of ETo, respectively) provided the best moisture conditions for microbial activities.
\end{abstract}

Key words: Biological soil properties. Soil nitrogen. Vigna unguiculata. Desertification.

\section{Resumo}

O objetivo deste estudo foi avaliar a biomassa microbiana e os estoques totais de carbono orgânico e nitrogênio de um Neossolo Flúvico irrigado, cultivado com duas cultivares de feijão-caupi, no município de Bom Jesus, Piauí. O experimento foi instalado em delineamento experimental em blocos ao acaso dispostos em parcelas subdivididas, sendo as subparcelas cinco lâminas de irrigação por aspersão $(\mathrm{L} 1=108,2 ; \mathrm{L} 2=214,7 ; \mathrm{L} 3=287,9 ; \mathrm{L} 4=426,1$ e $\mathrm{L} 5=527,7 \mathrm{~mm})$ e as parcelas duas cultivares de feijão-caupi (Aracê e Tumucumaque). Foram coletas amostras de solo na profundidade de 0-0,20 $\mathrm{m}$ para as avaliações da respiração basal do solo, carbono da biomassa microbiana, quociente metabólico, quociente microbiano, teor e estoque de carbono e nitrogênio do solo. A respiração basal do solo, carbono da biomassa microbiana, quociente metabólico e quociente microbiano são influenciados

\footnotetext{
${ }^{1}$ Prof ${ }^{a}$, Universidade Federal do Piaú, UFPI, Campus Professora Cinobelina Elvas, Bom Jesus, PI, Brasil. E-mail: larissa. diogenes@hotmail.com

2 Discente, Curso de Doutorado, Dept ${ }^{\circ}$ de Ciência do Solo, Universidade Federal de Lavras, UFLA, Departamento de Ciência do Solo, Lavras, MG, Brasil. E-mail: filhoze04@hotmail.com

${ }^{3}$ Mestres em Solos e Nutrição de Plantas, UFPI, Campus Prof ${ }^{a}$ Cinobelina Elvas, CPCE, Bom Jesus, PI, Brasil. E-mail: alefrancotorres@hotmail.com; joaoirenefilho@yahoo.com.br

${ }^{4}$ Profs., Universidade Federal do Recôncavo da Bahia, UFRB, Centro de Ciências Agrárias, Ambientais e Biológicas, Cruz das Almas, BA, Brasil. E-mail: juliocnobrega@gmail.com; rafaela.nobrega@gmail.com

5 Pesquisador, Empresa Brasileira de Pesquisa Agropecuária, Embrapa Meio-Norte, Teresina, PI, Brasil. E-mail: aderson.andrade@ embrapa.br

* Author for correspondence
} 
pela interação entre cutivares de feijão-caupi e lâminas de irrigação. A cultivar Aracê apresentou maior estímulo a comunidade microbiana, enquanto as lâminas de irrigação com 214,7 e 287,9 mm (60 e 90\% da ETo, respectivamente) proporcionaram as melhores condições de umidade a atividade microbiana.

Palavras-chave: Atributos biológicos do solo. Nitrogênio do solo. Vigna unguiculata. Desertificação.

\section{Introduction}

Cowpea [Vigna unguiculata (L.) Walp.] is the main subsistence crop in north and northeast Brazil (ANDRADE JÚNIOR et al., 2014). Due to its short life cycle and high tolerance to water stress compared to many other crops, cowpea is able to develop satisfactorily even in areas with limited rainfall (FREIRE FILHO et al., 2007). However, when managed well, irrigation can contribute to the increase of above-ground biomass and crop yield (ANDRADE JÚNIOR et al., 2014).

Irrigated agriculture in semi-arid regions, when poorly planned and performed, can contribute to soil degradation (CORRÊA et al., 2009). Dantas et al. (2012) evaluated the soil quality under different land use types and management practices in the Jaguaribe Irrigated Perimeter $-\mathrm{CE}$ and observed a reduction in total organic carbon (TOC) and total nitrogen (TN), ranging from 2.72 to $1.4 \mathrm{~kg} \mathrm{dag}^{-1}$ and 0.21 to 0.1 dag $\mathrm{kg}^{-1}$ for TOC and NT, respectively, in a depth of 0-0.05 m. Bona et al. (2006), when evaluating TOC levels in spraying irrigation systems, found that soil organic matter decomposition rates increased by 19 and $15 \%$ in one year in the soil under conventional tillage and no-tillage, respectively; with no effect of irrigation. According to the authors, this increase could be explained by the greater water availability for heterotrophic microbiota. However, Amaral et al. (2011), when evaluating physical and chemical attributes of an Oxisol cultivated with cowpea under different irrigation regimes, found higher soil fertility in irrigated areas because of increased amounts of base values, cation exchange capacity, and base saturation.

Soil microbial biomass, which is the living part of soil organic matter composed of fungi, bacteria, actinomycetes, and protozoa (FIGUEIREDO et al., 2007), can be influenced by temperature, $\mathrm{pH}$, aeration, and soil water availability (NASCIMENTO et al., 2010). According to Martins et al. (2010), greater water availability provides better conditions for the development of soil microorganisms, significantly reducing the metabolic quotient. In general, irrigation raises the levels of organic carbon, creating a favorable environment for soil microbes (COSTA et al., 2013), as also reported by Bona et al. (2006).

Given that irrigation is crucial for cowpea cultivation in dry periods in the state of Piaui (AMARAL et al., 2011), the use of biological indicators related to decomposition processes of matter organic to evaluate soil quality can provide subsidies for better soil management planning in irrigated areas of the semiarid region of northeast Brazil. Nowadays, these areas are subject to severe desertification, especially in the state of Piauí (CARNEIRO et al., 2012; ARAÚJO et al., 2013). In Piauí, soils degraded by a combination of erosion and desertification occupy an area of $8,0006.130 \mathrm{~km}^{2}$.

The objective of this study was to quantify the total and storage levels of organic carbon and nitrogen, microbial respiration and microbial biomass of a Quartzarenic Neosol cultivated with two cowpea cultivars in Piauí state, Brazil.

\section{Material and Methods}

The study was conducted in the municipality of Bom Jesus $\left(09^{\circ} 05^{\prime} 20,4^{\prime \prime} \mathrm{S}, 4^{\circ} 144^{\prime} 32^{\prime \prime} \mathrm{W}, 238 \mathrm{~m}\right.$ altitude), located in the state Piauí, Brazil. The soil of the experimental area is classified as Quartzarenic Neosol (JACOMINE et al., 1986). The climate is dry and sub-humid, with a dry season in the summer. The rainy season extends from November/ December to April/May (ANDRADE JÚNIOR et al., 2004). Average temperatures and humidity levels during the study period are shown in Figure 1 . 
Figure 1. Values of temperature and average humidity accumulated during the experiment in Bom Jesus, Piauí, Brazil.

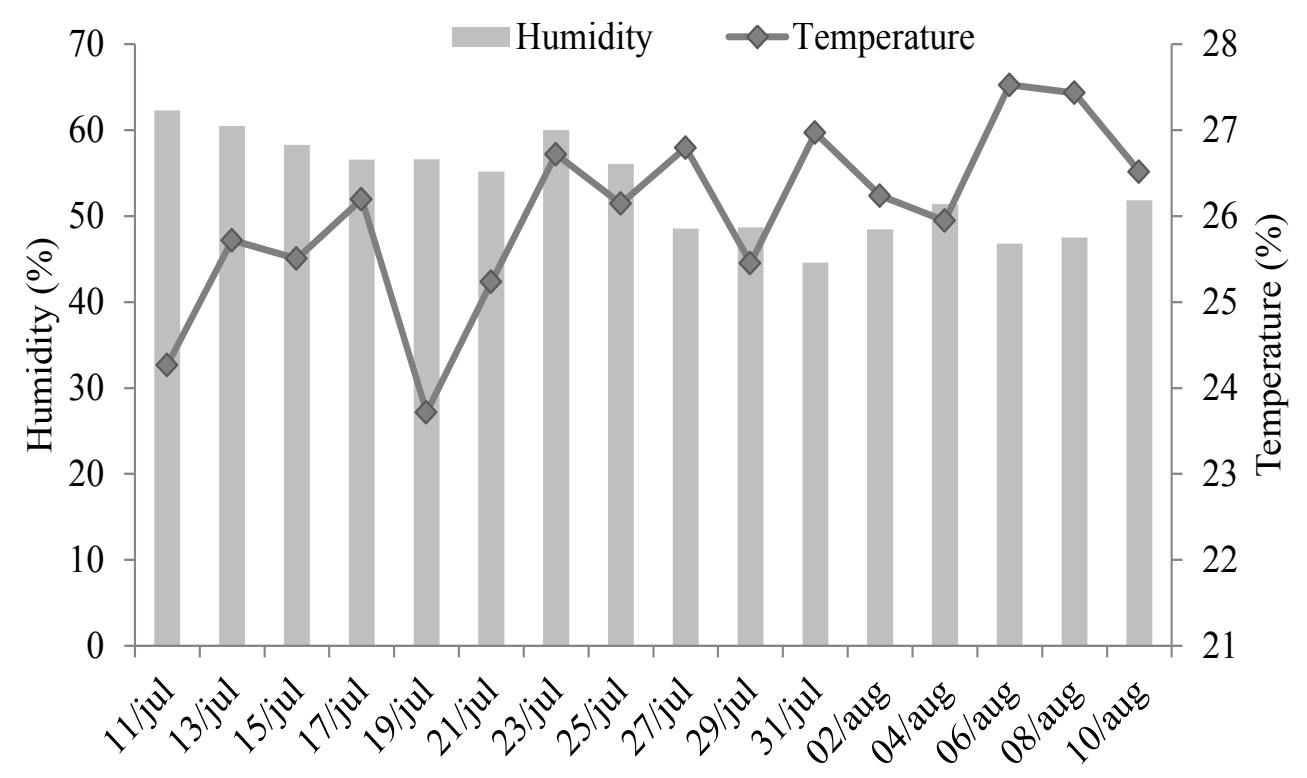

The area was covered with pasture until 1996, with no management for the subsequent 15 years, presenting only grasses and native species at an early stage of growth. In June 2011, the area was barred for the set-up of the experiment (cowpea cultivation) and submitted to five irrigation regimes $(\mathrm{L} 1=108.2 ; \mathrm{L} 2=214.7$; 3 = 287.9; L4 = 426.1 and L5 $=527.7 \mathrm{~mm}$ ), arranged in a split plot design (cultivars in the plots and irrigation subplots). Each irrigated band was formed by four blocks (12 x 12 $\mathrm{m})$. Each block consisted of two portions (6 x $12 \mathrm{~m})$ containing the two cultivars of cowpea (Aracê and Tumucumaque) and was seeded with a spacing of $0.80 \times 0.20 \mathrm{~m}$.

Irrigation was carried out using a sprinkler system, and each irrigation regime was estimated based on the daily evapotranspiration of reference (ETo) by Pemnan Monteith according to Allen et al. (1998) (30, 60, 90, 120 and $150 \%$ of ETo). The irrigation systems were applied following a fixed irrigation; irrigation was carried out on Mondays, Wednesdays, and Fridays. For Monday's irrigation, the accumulated ETo of Friday, Saturday, and
Sunday was applied; the same pattern was applied to all days. The adoption of this irrigation management aimed at facilitating the implementation of the application of the treatments on weekdays.

Soil preparation was conducted via plowing and harrowing. The addition of fertilizers was based on soil analysis (Table 1), following the nutritional requirements of cowpea. During harvesting, 100 $\mathrm{kg} \mathrm{ha}{ }^{-1}$ of triple superphosphate and $67 \mathrm{~kg} \mathrm{ha}^{-1}$ of potassium chloride were added. Fifteen days after germination, $67 \mathrm{~kg} \mathrm{ha}^{-1}$ of urea was applied. Other practices to control pests, diseases, and weeds were applied when needed according to the recommendations for this culture.

In August 2012, which is the flowering period of cowpea cultivars, eight single soil samples were collected at a depth of $0-0.20 \mathrm{~m}$. After homogenization, a composite sample of approximately $600 \mathrm{~g}$ was formed. The samples were transported to the laboratory and stored at $4{ }^{\circ} \mathrm{C}$. All analyses were carried out within 30 days after sampling. 
Table 1. Soil chemical parameters before the experiment in Bom Jesus, Piauí, Brazil.

\begin{tabular}{|c|c|c|c|c|c|c|c|c|c|c|c|c|c|c|c|c|}
\hline Depth & $\mathrm{O}^{(1)}$ & 2) & $P$ & $\mathrm{~K}^{+}$ & $a^{2+}$ & $\mathrm{Ig}^{2+}$ & $\mathrm{Na}^{+}$ & $\mathrm{Al}^{3+}$ & $\mathrm{H}+\mathrm{A}$ & $\mathrm{SB}^{(4)}$ & $\mathrm{T}^{(5)}$ & $\mathrm{V}^{(6)}$ & $\mathrm{m}^{(7)}$ & Sand & Silt & $\mathrm{Cl}_{\grave{s}}$ \\
\hline $\mathrm{m}$ & $\mathrm{g} \mathrm{kg}^{-1}$ & & $\mathrm{mg} \mathrm{dm}^{-3}$ & & -- & & $---\mathrm{c}$ & $\mathrm{nol}_{\mathrm{c}} \mathrm{d}$ & & - & & $---{ }^{-0}$ & & $-\cdots$ & $\mathrm{kg}^{-1}$ & - \\
\hline $0-0.20$ & 3.69 & 5.27 & 7.83 & 0.14 & 0.57 & 0.39 & 0.02 & 0.15 & 2.07 & 1.14 & 3.22 & 35.56 & 10.28 & 89.54 & 4.20 & 6.26 \\
\hline $0.20-0.40$ & 1.14 & 4.97 & 2.06 & 0.05 & 0.16 & 0.28 & 0.02 & 0.2 & 1.71 & 0.52 & 2.24 & 23.41 & 27.83 & 90.27 & 3.13 & 6.60 \\
\hline
\end{tabular}

${ }^{(1)} \mathrm{MO}=$ organic matter; ${ }^{(2)} \mathrm{pH}\left(\mathrm{H}_{2} \mathrm{O}\right) ;{ }^{(3)} \mathrm{H}+\mathrm{Al}=$ potential acidity; ${ }^{(4)} \mathrm{SB}=$ Basic Sum; ${ }^{(5)} \mathrm{T}=$ cátion exchange capacity; ${ }^{(6)} \mathrm{V}=$ base saturation; ${ }^{(7)} \mathrm{m}=$ aluminum saturation; Source: (ANDRADE JÚNIOR et al., 2014).

We conducted the following analyses: Basal soil respiration (BSR) (ALEF; NANNIPIERI, 1995), microbial biomass carbon (Cmic), which was estimated by the method of irradiation-extraction (MENDONÇA; MATOS, 2005), total organic carbon (TOC), determined by hot oxidation with potassium dichromate and titrated with ferrous ammonium sulfate according to a modified method of Walkley and Black (MENDONÇA; MATOS, 2005), and total nitrogen (TN), which followed the Kjeldahl method.

The microbial quotient (qMIC) was calculated as the ratio between Cmic and TOC (SPARLING, $1992)$ and the metabolic quotient $\left(q \mathrm{CO}_{2}\right)$ was determined as the ratio between BSR and Cmic (ANDERSON; DOMSCH, 1993).

Organic carbon storage (estC) and total nitrogen (estN) were calculated as described in Leite et al. (2003). For estC, at each depth, the expression estC $=(\mathrm{TOC} \times \mathrm{Ds} \mathrm{x}$ e) was used, in which estC represents the stock of total organic carbon at a certain depth; TOC is the total organic carbon content; Ds is the soil density at each depth, and " $\mathrm{e}$ " is the thickness of the layer. For nitrogen, the expression estN (TN $\mathrm{x}$ Ds $\mathrm{x}$ e) was used, where estN is the stock of total soil nitrogen in a given depth and $\mathrm{TN}$ is the total nitrogen content.

The results were submitted to analysis of variance, and multiple comparisons of the averages were analyzed by the Scott-Knott test $(\mathrm{p} \leq 0.05$ ) using Sisvar software (FERREIRA, 2014).

\section{Results and Discussion}

We observed an individual effect of irrigation on the variables $\mathrm{TN}, \mathrm{TOC}$, estN, and estC. There was an interaction $(p<0.05)$ between the cowpea cultivars and irrigation regimes for the following variables: RBS, cMIC, $q \mathrm{CO}_{2}$, and qMIC (Table 2).

Table 2. Mean square values for microbiological attributes and carbon and nitrogen storage in the soil cultivated with cowpea cultivars under different irrigation regimes.

\begin{tabular}{cccccccccc}
\hline Variation sources & $\mathrm{GL}^{(1)}$ & $\mathrm{RBS}^{(2)}$ & $\mathrm{Cmic}^{(3)}$ & $q \mathrm{CO}_{2}^{(4)}$ & $\mathrm{Qmic}^{(5)}$ & $\mathrm{NT}^{(6)}$ & $\mathrm{COT}^{(7)}$ & $\mathrm{EstN}^{(8)}$ & $\mathrm{EstC}^{(9)}$ \\
\hline Blocks & 3 & $13.63^{\mathrm{ns}}$ & $2796.00^{\text {ns }}$ & $0.09^{\text {ns }}$ & $36.83^{\text {ns }}$ & $0.01^{\text {ns }}$ & $1.28^{\text {ns }}$ & $0.04^{\text {ns }}$ & $14.32^{\text {ns }}$ \\
Cultivars (C) & 1 & $111.16^{\text {ns }}$ & $131947.00^{*}$ & $9.15^{*}$ & $3019.95^{*}$ & $0.04^{\text {ns }}$ & $0.08^{\text {ns }}$ & $0.48^{\text {ns }}$ & $0.01^{\text {ns }}$ \\
Residue (C) & 3 & 105.03 & 1139.00 & 0.04 & 8.37 & 0.01 & 0.27 & 0.12 & 3.14 \\
Irrigation regime (L) & 4 & $428.84^{*}$ & $1147.00^{\text {ns }}$ & $0.24^{*}$ & $91.60^{*}$ & $0.02^{*}$ & $3.67^{*}$ & $0.19^{*}$ & $37.40^{*}$ \\
C x L & 4 & $517.98^{*}$ & $8396.00^{*}$ & $0.26^{*}$ & $81.47^{*}$ & $0.01^{\text {ns }}$ & $1.85^{\text {ns }}$ & $0.04^{\text {ns }}$ & $10.48^{\text {ns }}$ \\
Residue (L) & 24 & 67.91 & 14065.00 & 0.06 & 18.26 & 0.01 & 1.08 & 0.05 & 12.40 \\
CV (C) \% & & 14.80 & 30.07 & 22.81 & 17.03 & 25.22 & 7.68 & 25.87 & 7.72 \\
CV (T) \% & & 11.90 & 21.57 & 27.54 & 27.15 & 16.39 & 15.39 & 16.56 & 15.34 \\
\hline
\end{tabular}

*significant at 5\% (F test); ns: not significant; ${ }^{(1)} \mathrm{GL}$ : degree of freedom; ${ }^{(2)} \mathrm{RBS}$ : basal soil respiration; ${ }^{(3)} \mathrm{Cmic}$ : microbial biomass carbon; ${ }^{(4)} \mathrm{qCO}_{2}$ : metabolic quotient; ${ }^{(5)} \mathrm{qMIC}$ : microbial quotient; ${ }^{(6)} \mathrm{NT}$ : total nitrogen content; ${ }^{(7)} \mathrm{TOC}$ : total organic carbon content; ${ }^{(8)}$ estN: nitrogen stock and ${ }^{(9)}$ estC: carbon stock. 
For BSR, higher values were obtained when the soil was cultivated with Aracê, with the following order for the irrigation regimes: L3 > L5 > L2 (Table 3). For Tumucumaque, higher averages were observed in L3 > L5 > L1 > L4. According to our results, L3 and L5 (90 and 150\% of ETo, respectively) were the best irrigation regimes for both cultivars. Overall, irrigation contributed to raising the addition of plant residues to the soil by crops (BONA et al., 2006; ANDRADE JÚNIOR et al., 2014), which stimulates soil microbiota (BONA et al., 2006). According to Tu et al. (2006), high microbial activity can mean rapid transformation of organic waste into nutrients for plants, which probably happened in this study with the application of L3. We also observed higher cMIC contents. However, according to the same authors, higher BSR values indicate stress for the microbial biomass, which could have been the case in the application of the L5 lamina, probably due to the lower $\mathrm{O}_{2}$ content in the soil, negatively impacting aerobic microbial communities.

Table 3. Basal soil respiration (RBS), microbial biomass carbon (Cmic), metabolic quotient $\left(q \mathrm{CO}_{2}\right)$, and microbial quotient (QMIC) in function of the irrigation regime and cowpea cultivars (Aracê and Tumucumaque) in a Quartzarenic Neosol from Bom Jesus, Piauí state, Brazil.

\begin{tabular}{|c|c|c|c|c|c|c|c|c|}
\hline \multirow{3}{*}{$\begin{array}{c}\text { Irrigation regime } \\
------m m------ \\
\end{array}$} & \multicolumn{2}{|c|}{ RBS } & \multicolumn{2}{|c|}{ Cmic } & \multicolumn{2}{|c|}{$q \mathrm{CO}_{2}$} & \multicolumn{2}{|c|}{ Qmic } \\
\hline & $----\mu \mathrm{gg}$ & $\mathrm{dia}^{-1}----$ & -----mg & $\mathrm{g}^{-1}-----$ & ug $\mathrm{CO}_{2}$ ug & -BM dia ${ }^{-1}$ & ---------- & b-------- \\
\hline & Aracê & Tumuc. & Aracê & Tumuc. & Aracê & Tumuc. & Aracê & Tumuc. \\
\hline $\mathrm{L}_{1}(108,2)$ & $58.02 \mathrm{bB}^{(1)}$ & $75.86 \mathrm{aA}$ & $189.70 \mathrm{aA}$ & $45.24 \mathrm{bA}$ & $0.32 \mathrm{bA}$ & $1.73 \mathrm{aA}$ & $22.66 \mathrm{aB}$ & $6.97 \mathrm{bA}$ \\
\hline $\mathrm{L}_{2}(214,7)$ & $70.51 \mathrm{aA}$ & $49.10 \mathrm{bB}$ & $193.76 \mathrm{aA}$ & $59.88 \mathrm{bA}$ & $0.38 \mathrm{bA}$ & $0.84 \mathrm{aB}$ & $31.84 \mathrm{aA}$ & $9.08 \mathrm{bA}$ \\
\hline $\mathrm{L}_{3}(287,9)$ & $77.11 \mathrm{aA}$ & $77.77 \mathrm{aA}$ & $184.81 \mathrm{aA}$ & $49.04 \mathrm{bA}$ & $0.45 \mathrm{bA}$ & $1.60 \mathrm{aA}$ & $33.47 \mathrm{aA}$ & $8.28 \mathrm{bA}$ \\
\hline $\mathrm{L}_{4}(426,1)$ & $57.41 \mathrm{bB}$ & $75.07 \mathrm{aA}$ & $141.48 \mathrm{aB}$ & $54.01 \mathrm{bA}$ & $0.43 \mathrm{bA}$ & $1.41 \mathrm{aA}$ & $20.38 \mathrm{aB}$ & $7.37 \mathrm{bA}$ \\
\hline $\mathrm{L}_{5}(527,7)$ & $74.89 \mathrm{aA}$ & $76.84 \mathrm{aA}$ & $138.54 \mathrm{aB}$ & $65.78 \mathrm{bA}$ & $0.55 \mathrm{bA}$ & $1.33 \mathrm{aA}$ & $20.05 \mathrm{aB}$ & $9.82 \mathrm{bA}$ \\
\hline
\end{tabular}

${ }^{(1)}$ Averages followed by the same uppercase letters in the column (between irrigation) and lower in line (among cowpea cultivars) do not differ by the Scott-Knott test at $5 \%$. ${ }^{(2)} \mathrm{L} 1=108.2 ; \mathrm{L} 2=214.7 ; \mathrm{L} 3=287.9 ; \mathrm{L} 4=426.1$, and L5 $=527.7 \mathrm{~mm}$.

For cMIC, the highest values were obtained for the Aracê cultivar, with the following order of irrigation regimes: L2 > L1 > L3. This behavior demonstrates that irrigation higher than $90 \%$ of ETo reduces soil cMIC contents, probably by reducing the $\mathrm{O}_{2}$ content in the soil, which decreases the oxidation activity of aerobic soil organisms. It can also be attributed to the highest average of cMIC in L1, L2, and L3, the largest production of above-ground biomass and roots of these cultivars, resulting in a higher deposition of organic substrates and roots.

Andrade Júnior et al. (2014), when evaluating the same cultivars under different water regimes, found that the highest total biomass for both cultivars was achieved with an irrigation regime of $350.0 \mathrm{~mm}$. In a similar study, Ferreira et al. (2007), when evaluating the dynamics of cMIC five times in a year and in different soil management systems in the Cerrado, found the highest values in the dry season (from 383.70 to $173.8 \mathrm{mg} \mathrm{kg}^{-1}$ ) and the lowest during flowering (350.3 to $133.15 \mathrm{mg} \mathrm{kg}$ ${ }^{1}$ ), indicating the influence of soil moisture on this variable.

The value of $q \mathrm{CO}_{2}$ indicated that the microbial biomass associated with the cultivar Arecê more efficiently used organic compounds, as evidenced by lower values compared with Tumucumaque for all irrigation regimes. Lower $q \mathrm{CO}_{2}$ values observed for Arecê indicate an efficient energy use, reflecting a more stable environment or a state closer to the equilibrium (MARTINS et al., 2010). For Tumucumaque, larger $q \mathrm{CO}_{2}$ values indicate higher release of carbon as $\mathrm{CO}_{2}$ to the atmosphere, leading 
lower carbon sequestration in microbial tissues (SILVA et al., 2010).

A greater efficiency of soil microorganisms in the Arecê cultivar is also demonstrated when evaluating qMIC values that presented the highest averages in L2 and L3. Soil moisture conditions most favorable for the use of microbial biomass carbon during flowering of cowpea cultivars are given with ETo values between 60 and 90\% (between 214.7 and $287.9 \mathrm{~mm}$ of water applied, respectively). According to Jakelaitis et al. (2008), under normal conditions, qMIC ranges from 1 to 4\%. However, values lower than $1 \%$ can be attributed to some factors limiting the activity of the microbial biomass, as verified for Tumucumaque. In this case, the low values observed for the cultivar may have been caused by the low nutritional quality of organic matter, restricting the use of organic carbon my microbial biomass (GAMA-RODRIGUES, 2008).

In terms of irrigation regimes, qMIC values were lower with the application of L1, L4 and L5 (Table 3), suggesting that both high (L4 and L5) and low
(L1) contents of water in the soil can reduce qMIC. According to Cunha et al. (2011), variations in qMIC values can reflect the pattern of soil organic matter input, the conversion efficiency of organic carbon to microbial carbon, ground carbon loss, and the stabilization of organic carbon by mineral soil fractions.

Soil nitrogen levels and estN values were larger in L5 (Figure 2a, b). According to Frazão at al. (2010), the increase of moisture in dry soil stimulates digestion and causes a peak of available nitrogen release, which is what probably happens with the application of irrigation systems. However, nitrogen mineralization tends to decrease as the soil moisture approaches the saturation point due to incomplete decomposition of organic matter (CANTARELLA et al., 2007). Silva et al. (2007) reported higher nitrogen concentration (1.23 to $0.98 \mathrm{~g} \mathrm{~kg}^{-1}$ ) in soil samples collected in February, considered the rainiest season, while in October, the driest period, the values ranged from 1.00 to 075 $\mathrm{g} \mathrm{kg}^{-1}$.

Figure 2. Total nitrogen content (a) and nitrogen stock (b) evaluated in terms of irrigation regimes under cultivation of cowpea cultivars in a Quartzarenic Neosol in Bom Jesus, Piauí, Brazil. L1 = 108.2; L2 = 214.7; L3 = 287.9; L4 = 426.1, and L5 $=527.7 \mathrm{~mm}$.
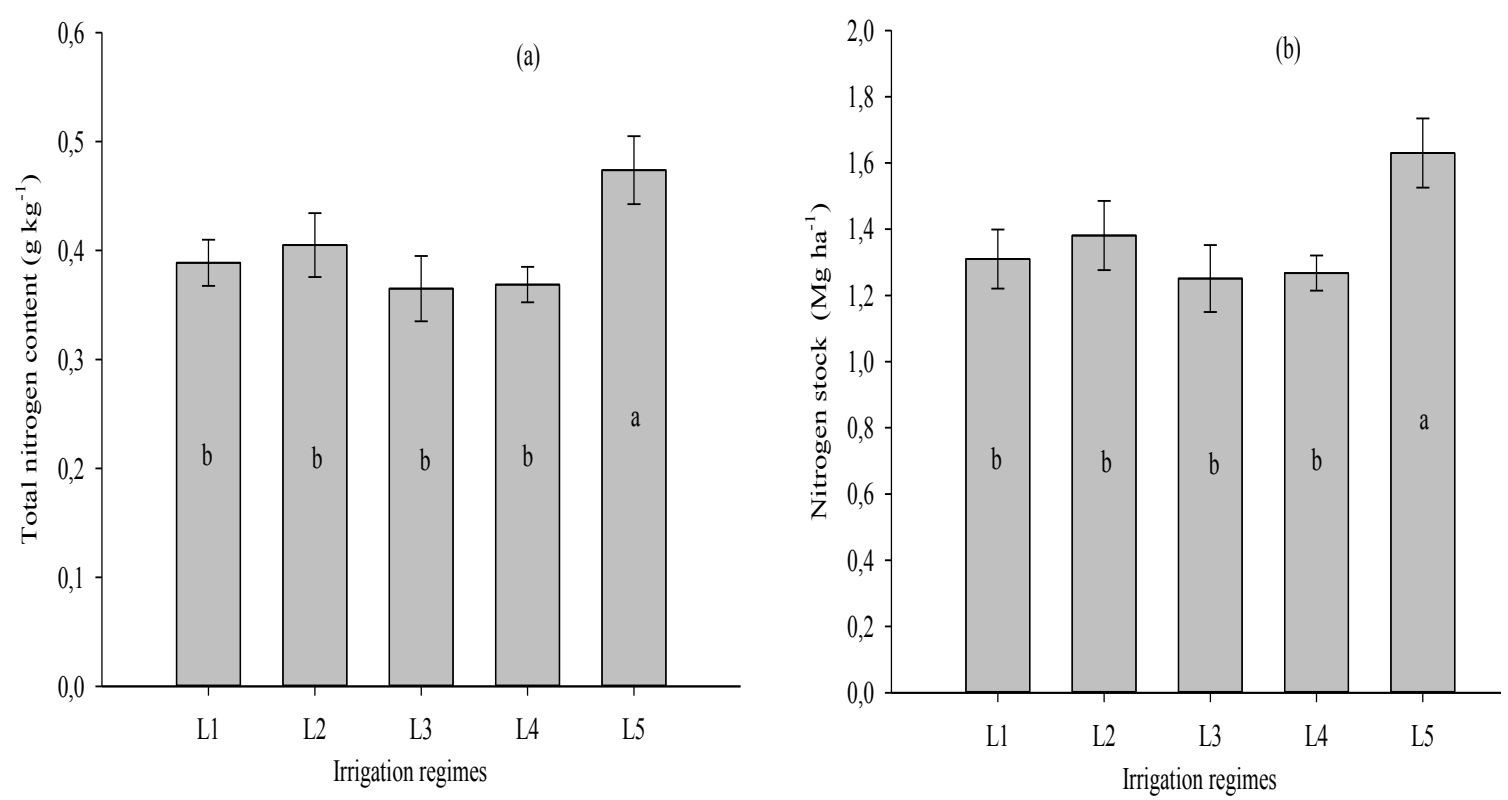
The TOC and the estC contents (Figure 3 a, b) showed a similar behavior, with the lowest values in L2 and L3, which provided the greatest mineralization of soil organic matter. As irrigation can enhance the mineralization of organic matter, the moisture conditions most favorable for microbial activity may reflect the increase in organic matter decomposition rates (PEREIRA et al., 2009). Bona et al. (2006) found that irrigation increased carbon levels in cultivation systems (up to $19 \%, 1.6 \mathrm{t} \mathrm{ha}^{-1}$ $\left.\mathrm{yr}^{-1}\right)$; this increase can be attributed to an average reduction of $46 \%$ of the deficit water by irrigation compared to no irrigation throughout the growth cycle and development of plants. According to the authors, it was estimated that for every mm of water supplied by irrigation, $8 \mathrm{~kg} \mathrm{ha}^{-1} \mathrm{yr}^{-1}$ carbon were added; after eight years, the irrigated area received approximately $12.7 \mathrm{tha}^{-1}$ carbon in the form of plant residue. However, the effect provided by the plant residue inputs was counterbalanced by increased rates of soil organic matter decomposition.

Figure 3. Total organic carbon content (a) and carbon stock (b) evaluated in terms of irrigation regimes under cultivation of cowpea cultivars in a Quartzarenic Neosol in Bom Jesus, Piauí, Brazil. L1 = 108.2; L2 = 214.7; L3 = 287.9; $\mathrm{L} 4=426.1$, and $\mathrm{L} 5=527.7 \mathrm{~mm}$.

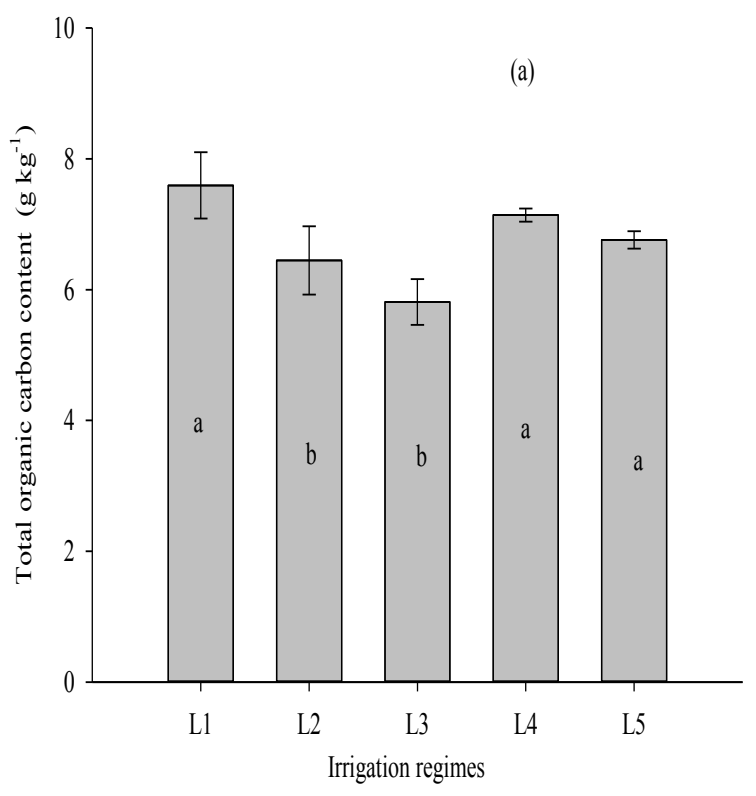

For this study, it can be concluded that the cultivar Aracê positively influenced the soil microbial community when compared with Tumucumaque, due to increased Cmic and Qmic values and decreased $q \mathrm{CO}_{2}$ rates. This effect is determined by the higher amount of plant residues in the soil, as verified by Andrade Júnior et al. (2014). However, the effects of cultivars on soil biota and estC and estN vary due to the applied irrigation regime, which was observed in this study when irrigation varied between 60 and $90 \%$ of ETo.

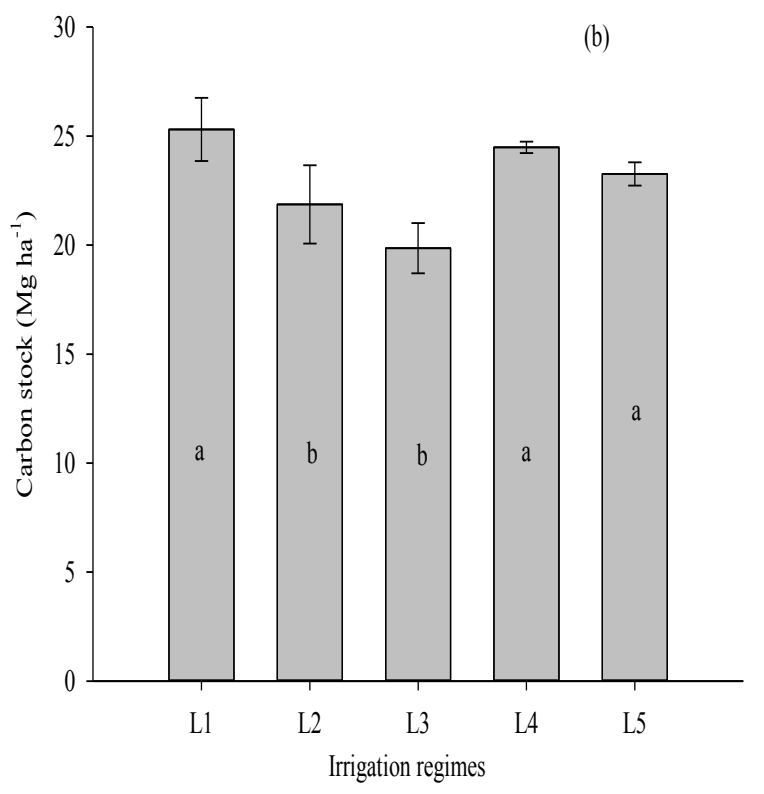

In this sense, the results of this study demonstrate that both cowpea cultivar and irrigation system influence soil microbial activities and soil organic matter contents, which is an important fact to be considered in the management of irrigated areas. Therefore, choosing plant species that provide highest amounts of plant residue is critical to reduce soil degradation risks and, consequently, the process of desertification, which has already reached some areas in the state Piaui (e.g. Gilbués Desertification Center, south of Piaui). 


\section{Conclusions}

Basal soil respiration, microbial biomass carbon, metabolic quotient, and microbial quotient are influenced by the interaction between cowpea cultivars and irrigation.

The cultivar Aracê shows greater stimulus to the microbial community, while irrigation with 214.7 and $287.9 \mathrm{~mm}$ (60 and $90 \%$ of ETo, respectively) provides the best conditions for microbial activity.

Irrigation with 108.2, 426.1, and $527.7 \mathrm{~mm}$ (30, 120 , and $150 \%$ of ETo, respectively) promotes an increase in soil carbon, while irrigation with 527.7 $\mathrm{mm}$ provides more nitrogen.

\section{Acknowledgements}

The authors thank the Coordination of Higher Education Personnel Training (Capes) and the National Council for Scientific and Technological Development $(\mathrm{CNPq})$ for granting the scholarships.

\section{References}

ALLEN, R. G.; PEREIRA, L.; RAES, D.; SMITH, M. Crop evapotranspiration: guidelines for computing crop water requirements. Rome: FAO, 1998. 297 p. (FAO: Irrigation and Drainage Paper, 56).

ALEF, K.; NANNIPIERI, P. Methods in applied soil microbiology and biochemistry. London: Academic, $1995.576 \mathrm{p}$.

AMARAL, F. H. C.; SILVA JÚNIOR, G. B.; NÓBREGA, J. C. A.; COSTA, E. M.; SILVA, A. F. T.; NÓBREGA, R. S. A. Atributos químicos e físicos de um Latossolo Amarelo cultivado com feijão-caupi sob diferentes sistemas de irrigação. Revista Brasileira de Ciências Agrárias, Recife, v. 6, n. 3, p. 467-473, 2011.

ANDERSON, T. H.; DOMSCH, K. H. The metabolic quotient $\left(q \mathrm{CO}_{2}\right)$ as a specific activity parameter to assess the effects of environmental conditions, such as $\mathrm{pH}$, on the microbial biomass of forest soils. Soil Biology \& Biochemistry, Oxford, v. 25, n. 3, p. 393-395, 1993.

ANDRADE JÚNIOR, A. S.; BASTOS, E. A.; BARROS, A. H. C.; SILVA, C. O.; GOMES, A. A. N. Classificação climática do Estado do Piauí. Teresina: Embrapa MeioNorte, 2004. 86 p.
ANDRADE JÚNIOR, A.S.; IRENE FILHO, J.; FERREIRA, J.O.P.; RIBEIRO, V.Q.; BASTOS, E.A. Medidas de crescimento em cultivares de feijão-caupi submetidas a diferentes regimes hídricos. Comunicata Scientiae, Bom Jesus, v. 5, n. 2, p. 187-195, 2014.

ARAÚJO, A. S. F.; CESARZ, S.; LEITE, L. F. C.; BORGES, C. D.; TSAI, S. M.; EISENHAUER, N. Soil microbial properties and temporal stability in degraded and restored lands of Northeast Brazil. Soil Biology \& Biochemistry, Oxford, v. 66, n. 1, p. 175-181, 2013.

BONA, F. D.; BAYER, C.; BERGAMASCHI, H.; DIECKOW, J. Carbono orgânico no solo em sistema irrigados por aspersão sob plantio direto e preparo convencional. Revista Brasileira de Ciência do Solo, Viçosa, MG, v. 30, n. 5, p. 911-920, 2006.

CANTARELLA, H. Nitrogênio. In: NOVAIS, R. F.; ALVAREZ, V. V. H.; BARROS, N. F.; FONTES, R. L. F.; CANTARUTTI, R. B.; NEVES, J. C. L. (Ed.). Fertilidade do solo. Viçosa, MG: SBCS, 2007. p. 375470.

CARNEIRO, R. F. V.; CARDOZO JÚNIOR, F. M.; PEREIRA, L. F.; ARAÚJO, A. S. F.; SILVA, G. A. Fungos micorrízicos arbusculares como indicadores da recuperação de áreas degradadas no Nordeste do Brasil. Revista Ciência Agronômica, Fortaleza, v. 43, n. 4, p. 648-657, 2012.

CORRÊA, R. M.; M. B. G. S.; FERREIRA, R. L. C.; FREIRE, F. J.; PESSOA, L. G. M.; MIRANDA, M. A.; MELO, D. V. M. Atributos químicos de solos sob diferentes usos em perímetro irrigado no semiárido de Pernambuco. Revista Brasileira de Ciência do Solo, Viçosa, MG, v. 33, n. 2, p. 305-314, 2009.

COSTA, A. R.; SATO, J. H.; RAMOS, M. L. G.; FIGUEIREDO, C. C.; SOUZA, J. P.; ROCHA, O. C.; GUERRA, A. F. Microbiological properties and oxidizable organic carbon fractions of an Oxisol under coffee with split phosphorus applications and irrigation regimes. Revista Brasileira de Ciência do Solo, Viçosa, MG, v. 37, n. 1, p. 55-65, 2013.

CUNHA, E. Q.; STONE, L. F.; FERREIRA, E. P. B.; DIDONET, A. D.; MOREIRA, J. A. A.; LEANDRO, W. M. Sistemas de preparo do solo e culturas de cobertura na produção orgânica de feijão e milho. II - atributos biológicos do solo. Revista Brasileira de Ciência do Solo, Viçosa, MG, v. 35, n. 2, p. 603-611, 2011.

DANTAS, J. D. N.; OLIVEIRA, T. S.; MENDONÇA, E. S.; ASSIS, C. P. Qualidade de solo sob diferentes usos e manejos no Perímetro Irrigado Jaguaribe/Apodi, CE. Revista Brasileira de Engenharia Agrícola e Ambiental, Campina Grande, v. 16, n. 1, p. 18-26, 2012. 
FERREIRA, D. F. Sisvar: a guide for its bootstrap procedures in multiple comparisons. Ciência $e$ Agrotecnologia, Lavras, v. 38, n. 2, p. 109-112, 2014.

FERREIRA, E. A. B.; RESCK, D. V. S.; GOMES A. C.; RAMOS, M. L. G. Dinâmica do carbono da biomassa microbiana em cinco épocas do ano em diferentes sistemas de manejo do solo no cerrado. Revista Brasileira de Ciência do Solo, Viçosa, MG, v. 31, n. 6, p. 16251635, 2007.

FIGUEIREDO, C. C. de; RESCK, D. V. S.; GOMES, A. C.; FERREIRA, E. A. B.; RAMOS, M. L. G. Carbono e nitrogênio da biomassa microbiana em resposta a diferentes sistemas de manejo em um Latossolo Vermelho no Cerrado. Revista Brasileira de Ciência do Solo, Viçosa, MG, v. 31, n. 3, p. 551-562, 2007.

FRAZÃO, L.A.; PICCOLO, M. C.; FEIGL, B. J.; CERRI, C. C.; CERRI, C. E. P. Inorganic nitrogen, microbial biomass and microbial activity of a sandy Brazilian Cerrado soil under different land uses. Agriculture, Ecosystems \& Enviroment, Amsterdam, v. 135, n. 3, p. 161-167, 2010.

FREIRE FILHO, F. R.; ROCHA, M. M.; BRIOSO, P. S. T.; RIBEIRO, V. BRS Guariba: a white grain cowpea cultivar for the Brazilian Mid-North Region. Crop Breeding and Applied Biotechnology, Viçosa, MG, v. 6, n. 2, p. 175-176, 2007.

GAMA-RODRIGUES, E. F. Biomassa microbiana e ciclagem de nutrientes. In: SANTOS, G. A.; CAMARGO, F. A. O. (Ed.). Fundamentos da matéria orgânica do solo-ecossistemas tropicais e subtropicais. 2. ed. rev. atual. Porto Alegre: Metrópole, 2008. p. 159-170.

JACOMINE, P. K. T.; CAVALCANTI, A. C.; PESSOA, S. C. P.; BURGOS, N.; MELO FILHO, H. F. R.; LOPES, O. F.; MEDEIROS, L. A. R. Levantamento exploratórioreconhecimento de solos do Estado do Piauí. Rio de Janeiro: EMBRAPA-SNLCS, SUDENE-DRN, 1986. $782 \mathrm{p}$.

JAKELAITIS, A.; SILVA, A. A.; SANTOS, J. B.; VIVIAN, R. Qualidade da camada superficial de solo sob mata, pastagens e áreas cultivadas. Pesquisa Agropecuária Tropical, Goiânia, v. 38, n. 2, p. 118-127, 2008.
LEITE, L. F. C.; MENDONÇA, E. S.; MACHADO, P. L. O. A.; MATOS, E. S. Total $\mathrm{C}$ and $\mathrm{N}$ storage and organic $\mathrm{C}$ pools of a Red-Yellow podzolic under conventional and no tillage at the Atlantic forest zone, Southeastern Brazil. Australian Journal of Soil Research, Colingwood, v. 41, n. 4, p.717-730, 2003.

MARTINS, C. M.; GALINDO, I. C. L.; SOUZA, E. R.; POROCA, H. A. Atributos químicos e microbianos do solo em áreas em processo de desertificação no semiárido de Pernambuco. Revista Brasileira de Ciência do Solo, Viçosa, MG, v. 34, n. 6, p. 1883-1890, 2010.

MENDONÇA, E. S.; MATOS, E. S. Matéria orgánica do solo: métodos de análises. Viçosa, MG: UFV, 2005. $107 \mathrm{p}$.

NASCIMENTO, P. C.; LANI, J. L.; MENDONÇA, E. S.; ZOFFOLI, H. J. O.; PEIXOTO, H. T. M. Teores e características da matéria orgânica de solos hidromórficos do Espírito Santo. Revista Brasileira de Ciência do Solo, Viçosa, MG, v. 34, n. 2, p. 339-348, 2010.

PEREIRA, A. L.; CAMPOS, M. C. C.; SOUZA, Z. M.; CAVALCANTE, I. H. L.; SILVA, V. A.; MARTINS FILHO, M. V. Atributos do solo sob pastagens em sistema de sequeiro e irrigado. Ciência e Agrotecnologia, Lavras, v. 33, n. 2, p. 377-384, 2009.

SILVA, G. R.; SENA, W. L.; SILVA JUNIOR, M. L. Carbono e nitrogênio da biomassa microbiana como indicadores ambientais de um Latossolo Amarelo sob diferentes sistemas de manejo, Marituba, Pará. Revista Ciências Agrárias, Belém, v. 48, n. 1, p. 71-84, 2007.

SILVA, R. R.; SILVA M. L. N.; CARDOSO, E. L.; MOREIRA, F. M. S.; CURI, N.; ALOVISI, A. M. T. Biomassa e atividade microbiana em solo sob diferentes sistemas de manejo na região fisiográfica Campos das Vertentes - MG. Revista Brasileira de Ciência do Solo, Viçosa, MG, v. 34, n. 5, p. 1585-1592, 2010.

SPARLING, G. P. Ratio of microbial biomass carbon to soil organic as a sensitive indicator changes in matter. Australian Journal of Soil Research, Colingwood, v. 30, n. 2, p. 195-207, 1992.

TU, C.; RISTAINO, J. B.; HU, S. Soil microbial biomass and activity in organic tomato farming systems: Effects of organic inputs and straw mulching. Soil Biology \& Biochemistry, Oxford, v. 38, n. 2, p. 247-255, 2006. 
